\title{
Promises and challenges of personalized medicine to guide ARDS therapy
}

\author{
Katherine D. Wick ${ }^{1 *} \mathbb{0}$, Daniel F. McAuley², Joseph E. Levitt ${ }^{3}$, Jeremy R. Beitler ${ }^{4}$, Djillali Annane ${ }^{5,6}$, \\ Elisabeth D. Riviello ${ }^{7}$, Carolyn S. Calfee ${ }^{1,8}$ and Michael A. Matthay ${ }^{1,8}$
}

\begin{abstract}
Identifying new effective treatments for the acute respiratory distress syndrome (ARDS), including COVID-19 ARDS, remains a challenge. The field of ARDS investigation is moving increasingly toward innovative approaches such as the personalization of therapy to biological and clinical sub-phenotypes. Additionally, there is growing recognition of the importance of the global context to identify effective ARDS treatments. This review highlights emerging opportunities and continued challenges for personalizing therapy for ARDS, from identifying treatable traits to innovative clinical trial design and recognition of patient-level factors as the field of critical care investigation moves forward into the twenty-first century.
\end{abstract}

Keywords: Acute respiratory distress syndrome, Acute lung injury, Personalized medicine, COVID-19, Clinical trials

\section{Key lessons}

- Personalized medicine in ARDS is inherently challenging because of heterogeneous etiology and pathophysiology

- ARDS research need not focus exclusively on novel investigational therapies, as repurposing drugs that have been studied in untargeted/unenriched populations could be just as innovative and promising, including for COVID-19 ARDS

- Opportunities for targeting therapies include timing, clinical phenotypes, and biologic phenotypes

- Adaptive clinical trial design offers the chance to investigate multiple therapies quickly and flexibly

- Supportive interventions, such as ventilator management and fluid strategy, can also potentially be personalized

\footnotetext{
*Correspondence: katherine.wick@ucsf.edu

${ }^{1}$ Cardiovascular Research Institute, University of California San Francisco,

513 Parnassus Avenue, HSE 760, San Francisco, CA 94143, USA
}

Full list of author information is available at the end of the article
- Though existing drugs and supportive care strategies may be repurposed/targeted, novel therapies are also on the horizon

\section{Introduction}

A challenge in personalizing therapy in critical illness syndromes including ARDS is their inherent heterogeneity. Perhaps in part because of this heterogeneity, years of investigation into possible therapies for classical ARDS have not confirmed the benefit of any pharmacologic treatment. Despite these challenges, the field of ARDS treatment remains rich for investigation. At least two biologic phenotypes of ARDS have been identified, first in secondary analyses of clinical trials $[1,2]$, and now in large observational cohorts [3]. These phenotypes appear to respond differentially to both investigational and standard supportive therapies $[4,5]$. The understanding of not only the biology of ARDS, but also of its clinical presentation and timeline, is rapidly evolving [6]. Targeting both biologic phenotypes and specific clinical populations-for example, those that share a common risk factor or are identified early in their disease course-may 
be the key to advancing personalized medicine in ARDS. This review will consider specific pharmacologic and supportive therapies in ARDS that have not previously been proven to have benefit but that could hold promise if targeted to specific biological mechanisms (Fig. 1) or clinical/biologic phenotypes. Additionally, a new investigational therapy, mesenchymal stromal cells (MSCs), will be discussed. We will also explore the challenges of intelligent clinical trial design and the horizon for personalizing ARDS therapies in the global context.

\section{Targeting supportive therapy: personalized ventilator management}

Several studies suggest that mechanical ventilation strategy might be personalized for improved outcomes in ARDS. Ventilation-induced lung injury (VILI) may occur in some patients even when the standard tidal volumes of $6 \mathrm{~mL} / \mathrm{kg}$ predicted body weight (PBW) and plateau pressure $\leq$ of $30 \mathrm{~cm} \mathrm{H}_{2} \mathrm{O}$ are targeted [7-10]. There is evidence that some patients benefit more than others from low tidal volume (LTV) and that the likelihood of benefit is associated with the baseline plasma concentration of the receptor for advanced glycation end products (RAGE), a biomarker of alveolar type I cell injury [11]. The recent REST trial demonstrated no benefit of extracorporeal carbon dioxide removal to facilitate ultra-LTV [12]. Whether baseline biologic characteristics could identify populations that may benefit is yet to be determined, though no pre-planned subgroup analyses showed evidence of heterogeneous treatment effect. Personalizing ventilator management entails assessing patient-specific risk of VILI and then weighing the potential risk/benefit of interventions intended to attenuate VILI (Table 1).

Several strategies have been proposed to individualize tidal volumes, including tailoring settings to airway driving pressure, end-inspiratory transpulmonary pressure, waveform-derived stress index, end-expiratory lung volume, and electrical impedance tomography [13-17]. Airway driving pressure $(\Delta P=$ plateau pressure-PEEP) is perhaps the most readily accessible [13]. Adjusting tidal volume and PEEP to achieve driving pressures between 10 and $15 \mathrm{~cm} \mathrm{H}_{2} \mathrm{O}$ has been proposed $[18,19]$, and is a reasonable though unproven target. A driving pressure-limited strategy in most patients not requiring extracorporeal membrane oxygenation (ECMO) is feasible in patients with ARDS [19], and refractory high driving pressure despite ventilator optimization may help select patients who would benefit from ECMO [20]. Clinical efficacy of a driving pressure-targeted strategy to individualize tidal volume and PEEP warrants prospective testing in clinical trials.

To date, no one strategy for individualizing positiveend expiratory pressure (PEEP) has proven superior for improving survival [21-25], perhaps in part because of the competing risk of overdistension with higher PEEP [26]. Personalized positive end-expiratory pressure (PEEP) titration should seek to minimize atelectrauma and driving pressure without exacerbating

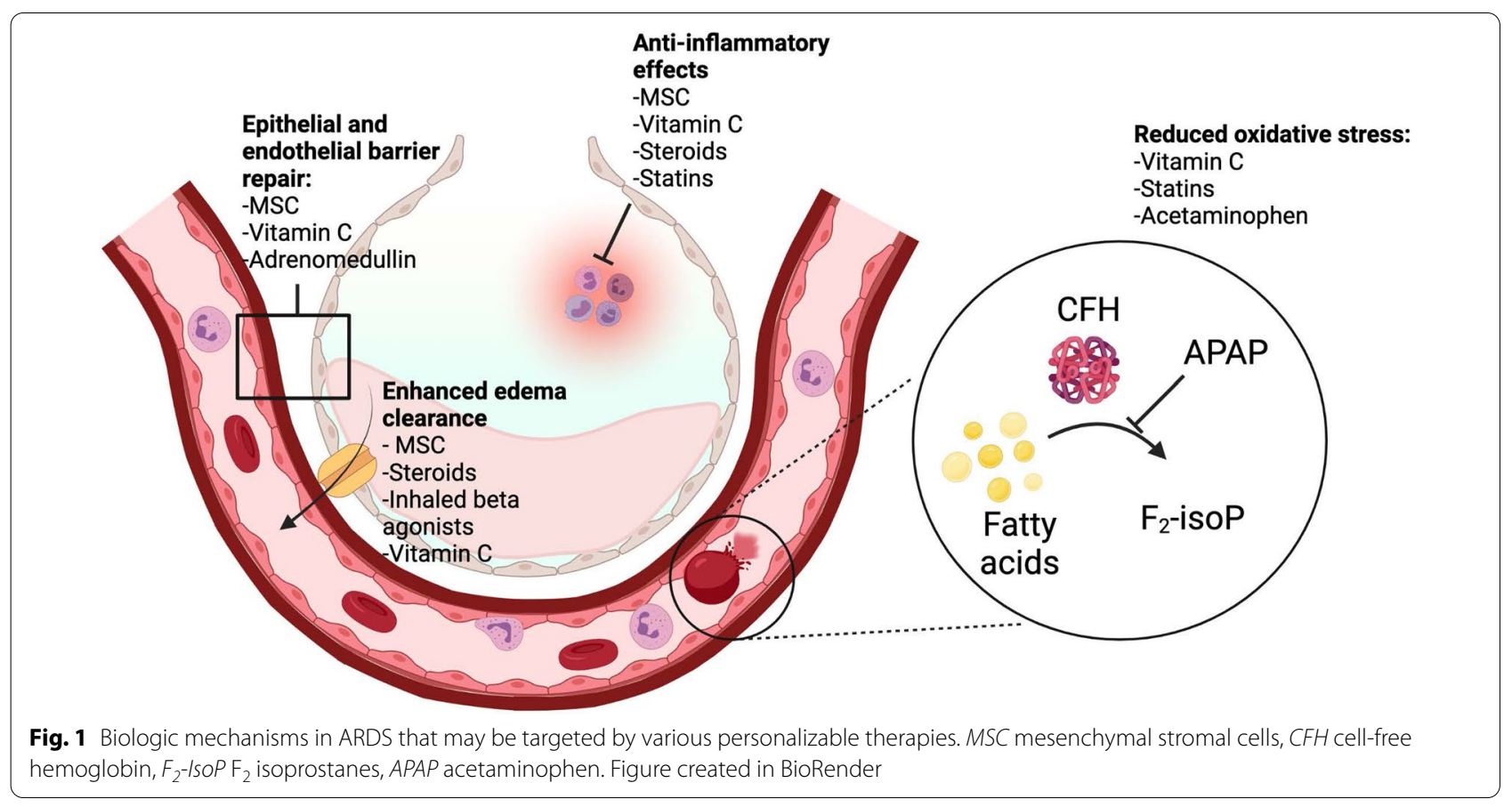


Table 1 Partial list of pivotal studies advancing precision ventilation for ARDS

\begin{tabular}{|c|c|}
\hline Parameter and study & Key contribution \\
\hline \multicolumn{2}{|l|}{ Tidal volume } \\
\hline Hager et al. [92] & $\begin{array}{l}\text { Reanalysis of the ARDSNet tidal volume trial demonstrated plateau pressure below } 30 \mathrm{~cm} \mathrm{H}_{2} \mathrm{O} \\
\text { was associated with additional improvement in survival, raising the possibility of residual VILI } \\
\text { despite current standard-of-care low tidal volume ventilation }\end{array}$ \\
\hline Amato et al. [13] & $\begin{array}{l}\text { Reanalysis of several clinical trials demonstrated changes in airway driving pressure mediated } \\
\text { effects of tidal volume (and PEEP) on mortality, suggesting driving pressure may be a useful } \\
\text { metric for individualizing tidal volume to patient-specific mechanics }\end{array}$ \\
\hline Pereira Romano et al. [19] & $\begin{array}{l}\text { Pilot clinical trial demonstrated feasibility of a driving pressure-limited strategy without ECMO, } \\
\text { laying the groundwork for a future trial of individualized tidal volumes }\end{array}$ \\
\hline \multicolumn{2}{|l|}{ PEEP } \\
\hline EPVent-1 and EPVent-2 trials $[22,93]$ & $\begin{array}{l}\text { Single and multi-center trials, respectively, that demonstrated PEEP individualized to esophageal } \\
\text { pressure, an estimate of pleural pressure, improved adjusted survival compared to an empirical } \\
\text { low-PEEP strategy, but did not affect survival compared to an empirical high-PEEP strategy }\end{array}$ \\
\hline Alveolar recruitment for ARDS trial (ART) [21] & $\begin{array}{l}\text { Multicenter trial demonstrated a stepwise recruitment maneuver combined with PEEP titrated to } \\
\text { highest respiratory system compliance, compared to an empirical low-PEEP strategy, increased } \\
\text { mortality; interpretation of the PEEP effect is limited by the aggressive, prolonged exposure to } \\
\text { extremely high airway pressures during the incremental/decremental recruitment maneuver }\end{array}$ \\
\hline LIVE trial [23] & $\begin{array}{l}\text { Multicenter trial demonstrated tailoring PEEP to radiographic findings (higher PEEP in patients } \\
\text { with non-focal opacities, lower PEEP if focal opacities) did not improve survival compared to an } \\
\text { empirical low-PEEP strategy, although misclassification of radiographs limits interpretation of } \\
\text { findings }\end{array}$ \\
\hline \multicolumn{2}{|c|}{ Weighting relative importance of ventilator parameters } \\
\hline Gattinoni et al. [27] & $\begin{array}{l}\text { Cohort study proposed mechanical power delivered by the ventilator, combining several ventila- } \\
\text { tor parameters into a unifying metric to quantify VILI risk }\end{array}$ \\
\hline Costa et al. [29] & $\begin{array}{l}\text { Cohort study that concluded driving pressure and respiratory rate were the key parameters of } \\
\text { mechanical power that influence mortality, also suggesting the effect on mortality of each } 1 \mathrm{~cm} \\
\mathrm{H}_{2} \mathrm{O} \text { increase in driving pressure was four times that of each } 1 \text { breath/min increase in respiratory } \\
\text { rate }\end{array}$ \\
\hline
\end{tabular}

overdistension, but how best to achieve these objectives at the bedside remains unclear.

One challenge to personalized ventilator management is that there is no unifying marker of VILI or VILI risk. Higher risk is typically assumed in patients with more severe ARDS (lower $\mathrm{PaO}_{2} / \mathrm{FiO}_{2}$ ) or evidence of tidal overdistension. The energy delivered by the ventilator to the respiratory system per unit time, termed mechanical power, has been proposed to quantify VILI risk and guide ventilator titration [27]. Mechanical power correlates with VILI in animal models and mortality in clinical cohorts [28, 29]. However, mechanical power does not directly address atelectrauma or regional mechanical heterogeneity, and doubt exists regarding whether its empirical formulation correctly weighs importance of individual ventilator parameters. Further study is required to optimize identification of patients at risk of VILI and the approach for personalizing mechanical ventilation to mitigate this risk [29].

\section{Differential treatment responses in ARDS biologic phenotypes}

Inflammatory phenotypes typically defined as hyperinflammatory/reactive and hypoinflammatory/uninflamed with distinct clinical outcomes have now been described in different settings in several studies of ARDS $[1,4,30]$. Recently, these inflammatory phenotypes have been described in both COVID-19 [31] and in patients with acute hypoxemic respiratory failure [32]. Thus, these phenotypes may represent "treatable traits" beyond the current syndromic definition of ARDS.

In a secondary analysis of the HARP-2 trial (simvastatin $80 \mathrm{mg}$ or placebo in patients with ARDS), patients in the hyperinflammatory subgroup had significantly increased 28-day survival when randomized to simvastatin [4]. In contrast, in an analysis of the SAILS study (rosuvastatin $10 \mathrm{mg}$ or placebo in patients with sepsis induced ARDS), there was no treatment effect in either group [2]. This difference may be related to differences in the study population (all-cause vs. sepsis-related) or the statins used (differences in dose and hydrophilicity).

Although these data support the concept of a precision medicine approach with simvastatin and other pharmacological therapies, it is important to highlight that these data should be regarded as hypothesis generating and need to be confirmed in prospective clinical trials. One final challenge to consider for enabling the translation of this precision medicine approach into prospective 
clinical trials and subsequently clinical practice is how to rapidly identify phenotypes at the bedside in real time. It is likely that plasma biomarkers, which are not routinely available, will be required to most accurately identify inflammatory phenotypes. The current lack of point-ofcare assays represents a significant barrier to the clinical implementation of ARDS phenotypes. Ongoing clinical trials such as the PHIND trial (NCT04009330) aim to develop a point-of-care assay that can identify hyperinflammatory and hypoinflammatory phenotypes rapidly at the bedside. Such assays to facilitate identification of phenotypes to guide pharmacological therapy will be an important step in delivering precision medicine at the bedside.

\section{New avenues for existing therapies: sepsis-related ARDS}

One strategy repurposing existing therapies in ARDS is to identify populations with shared clinical features or risk factors. For example, the role of cell-free hemoglobin $(\mathrm{CFH})$ as a mediator of sepsis-related organ dysfunction is the basis of ongoing investigation in patients with ARDS due to sepsis. Although sepsis is itself a heterogeneous syndrome, the underlying pathobiology of patients with sepsis-related ARDS may differ from patients with ARDS from other causes, especially in the case of extrapulmonary sepsis [33, 34]. Targeting patients with sepsis for testing new therapies is a promising enrichment strategy for ARDS clinical trials. The effects of CFH on endothelial dysfunction, oxidative stress, and inflammation may have particular relevance to sepsis-related ARDS $[35,36]$.

The red blood cell membrane is altered in sepsis [37], leading to the release of free hemoglobin, a potent oxidizing and pro-inflammatory mediator [35]. Vitamin C and acetaminophen may diminish the injurious effects of CFH. Vitamin C infusion for ARDS was tested in the double blinded CITRIS-ALI trial. 167 patients with sepsis and ARDS were randomized to receive either $50 \mathrm{mg} /$ $\mathrm{kg}$ vitamin $\mathrm{C}(n=84)$ or placebo $(n=83)$ every $6 \mathrm{~h}$ for $96 \mathrm{~h}$ [38]. Patients in the vitamin $\mathrm{C}$ arm had significantly lower mortality $(29.8 \%$ vs. $46.3 \%$ in the placebo group, $p=0.03)$, significantly more ICU-free days, and numerically more ventilator-free days [38].

Acetaminophen has also been shown to reduce concentrations of $\mathrm{F}_{2}$ isoprostanes, which are by-products of lipid peroxidation, among patients with sepsis $[39,40]$. These promising findings for the benefit of acetaminophen and vitamin $C$ in sepsis and sepsis-related ARDS are the basis for a planned phase 2 NHLBI-supported trial, Acetaminophen and Ascorbate in Sepsis: Targeted Therapy to Enhance Recovery (ASTER, NCT04291508), which will test both acetaminophen versus placebo and vitamin $\mathrm{C}$ versus placebo in a parallel design. Patients with sepsis and either evidence of shock or respiratory failure will be eligible for enrollment, facilitating an assessment not only of the effects of vitamin $\mathrm{C}$ and/or acetaminophen among patients with established ARDS due to sepsis, but also those at risk for sepsis-related ARDS. The ASTER trial is an important example of how a shared risk factor (sepsis) informs the investigation of repurposed therapies for ARDS.

\section{Lessons from the COVID-19 pandemic}

A small benefit of the devastating COVID-19 pandemic is the opportunity for studying treatment effects in a large population of patients with viral pneumonia as a shared risk factor for ARDS. This unprecedented wave of respiratory viral infection has dramatically increased the incidence of ARDS. In the USA, for example, the estimated incidence of severe pneumonia/ARDS during the COVID-19 pandemic was approximately 2.5 million cases per 18 months, as compared to 300,000 cases per 18 months prior to the pandemic (Fig. 2) [41]. Treatments with uncertain benefit in undifferentiated ARDS, including corticosteroids and specific antagonists of the IL-6 receptor, probably prevent disease progression and death in hospitalized adults with COVID-19 (Table 2) [42-45], effects that are likely additive [42, 46]. Findings from these studies underscore the importance of the timing of interventions in the disease course of lung injury (discussed further below). In the RECOVERY trial, treatment with $6 \mathrm{mg}$ of dexamethasone for 5 to 10 days resulted in a major survival benefit in patients with oxygen supplementation but not in those with early or mild disease who did not require oxygen support [47], suggesting a heterogeneous treatment effect by disease stage

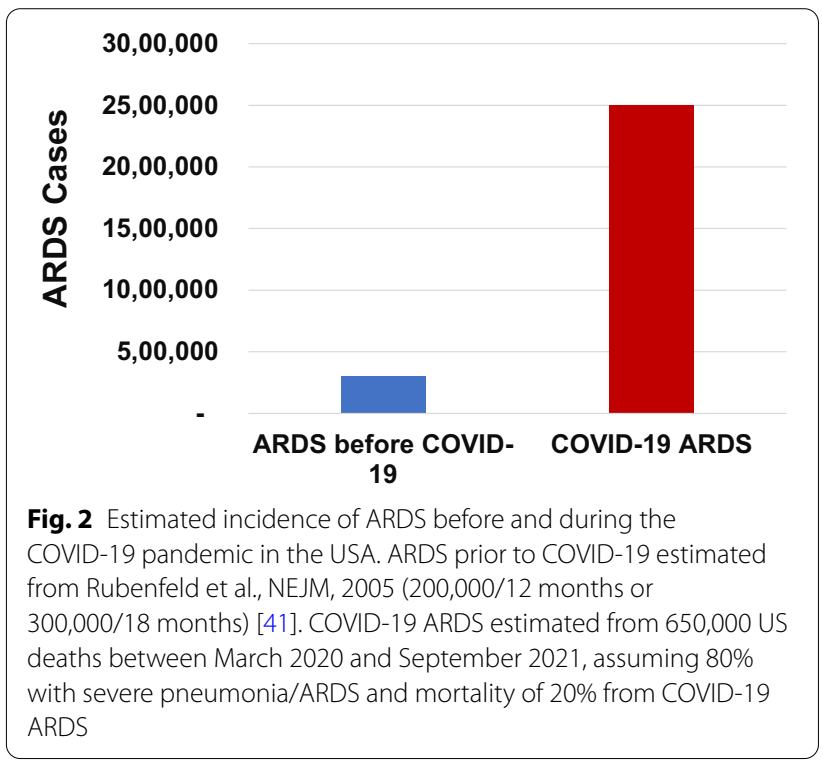




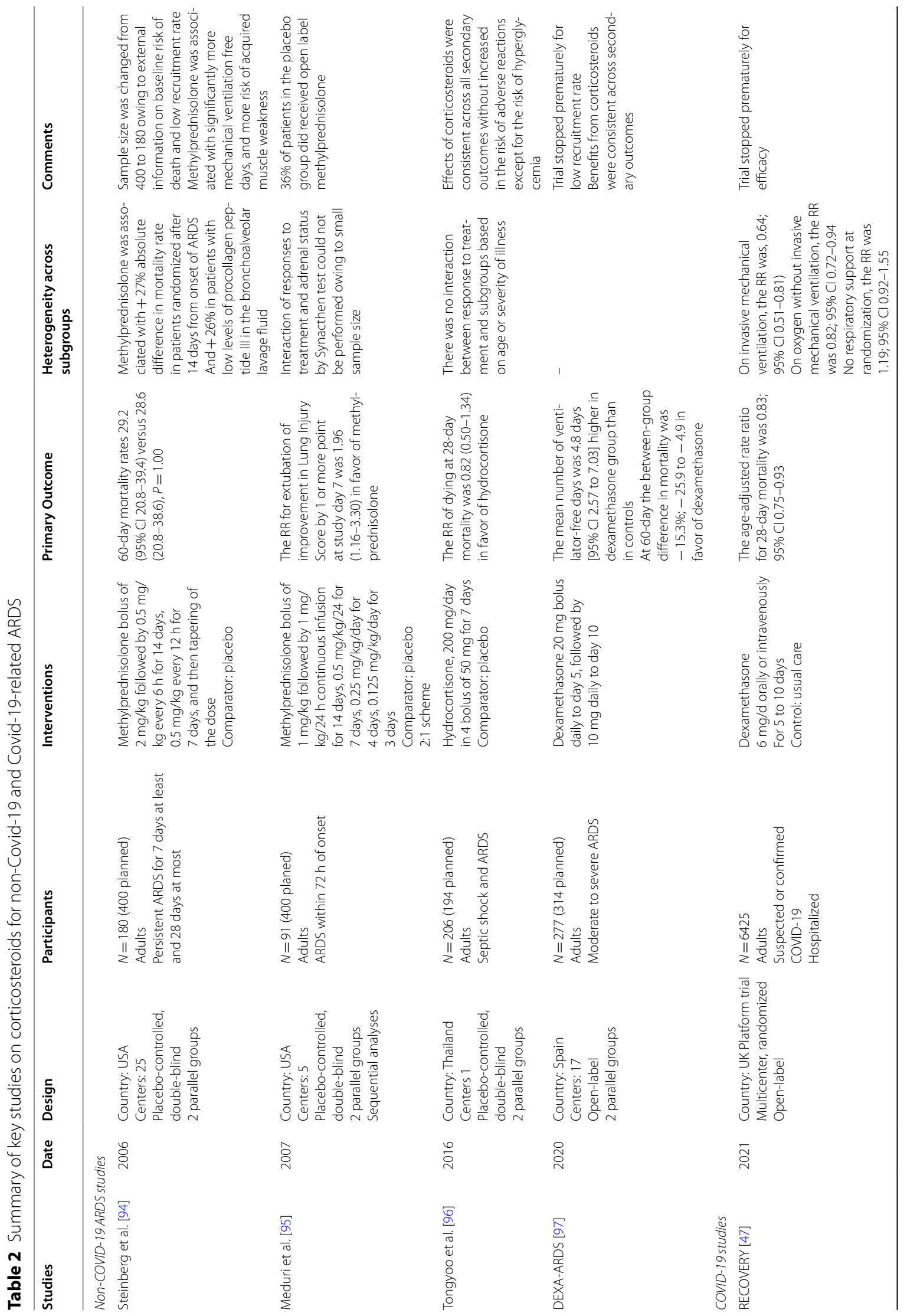




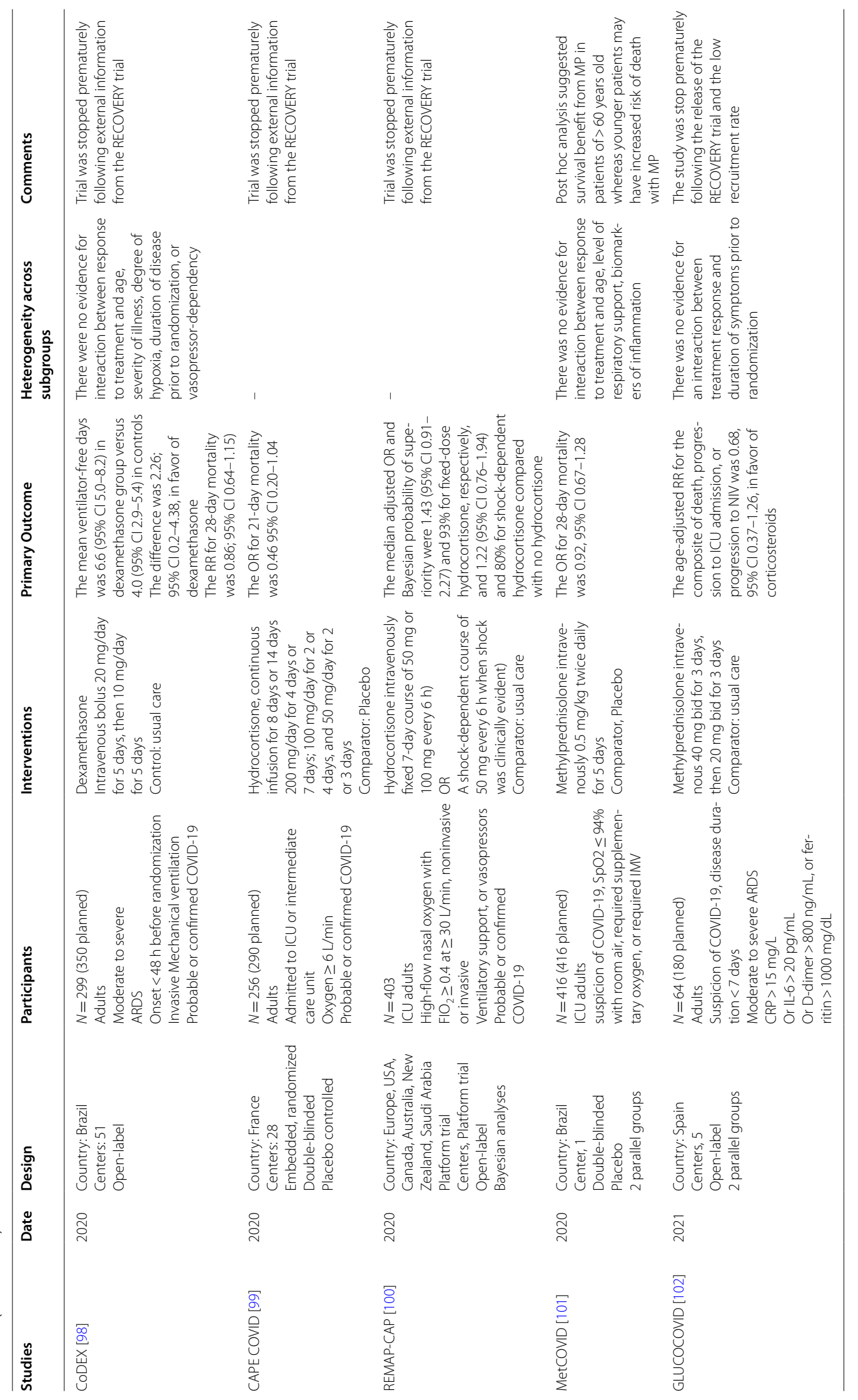


and severity. The survival benefit observed in RECOVERY trial participants receiving invasive mechanical ventilation (11\% mortality reduction) was comparable to the benefits observed with $200 \mathrm{mg}$ of hydrocortisone for 7 days in septic shock and ARDS (9\% mortality reduction) [48].

The variability in patients' response to corticosteroids or IL-6 receptor antagonists may partly be explained by the variability in patients' immune responses to SARSCoV-2 [49], demonstrating that while investigating ARDS due to a common risk factor is an important strategy, it does not guarantee homogeneous response. The heterogeneity in COVID-19 patients' responses to corticosteroids is in line with previous observations in non-COVID ARDS (Table 2) [50, 51]. Preventing the unsafe exposure of individuals to immunomodulating drugs such as corticosteroids and anti-cytokine monoclonal antibodies is of the utmost importance. Collectively artificial intelligence, omics tools and new generation of biomarkers may help designing individual fingerprints to guide immune modulation with corticosteroids in patients with ARDS regardless of the etiology or clinical phenotype (NCT04280497).

\section{Promising therapies in early ARDS: inhaled therapies}

Targeting early ARDS may be another strategy for identifying personalizable therapies. For example, patients with early acute lung injury may be targeted to prevent progression. Inhaled delivery of therapies for early treatment of acute lung injury may provide the benefit of rapid delivery of therapeutic doses directly to the target organ with less systemic toxicity. Inhaled therapies are not strictly limited to early lung injury. There is an ongoing phase II trial of inhaled adrenomedullin for intubated patients with ARDS (NCT 04417036); however, how personalization may be relevant to this therapy has not yet been explored as its safety in all ARDS still needs to be established in this trial.

Inhaled beta agonists have been shown to achieve therapeutic levels in pulmonary edema fluid of patients with ARDS [52] and increase alveolar fluid clearance (AFC) in experimental models of lung injury [53]. In a phase II trial of patients with ARDS, systemic salbutamol decreased extravascular lung water [54]; however, subsequent phase III trials of systemic [55] and inhaled [56] beta agonists were stopped early for futility or signal for harm. Inhaled corticosteroids have been shown to reduce the severity of lung injury in experimental models of ARDS and have synergistic effects with beta agonists in the treatment of asthma and chronic obstructive lung disease. In a phase 2 a trial, Festic et al. showed improvement in oxygenation measured by categorical $( \pm 20 \%)$ and continuous longitudinal change in the ratio of pulse oximetric oxygen saturation to the fraction of inspired oxygen $\left(\mathrm{SpO}_{2} / \mathrm{FiO}_{2}\right)$ in 60 patients at risk for development of ARDS treated with a combination of aerosolized budesonide $(0.5 \mathrm{mg} / 2 \mathrm{~mL})$ and formoterol $(20 \mathrm{mcg} / 2 \mathrm{~mL})$ relative to placebo ( $4 \mathrm{~mL} 0.9 \%$ saline) [57]. Importantly, none of the 29 patients treated with aerosolized budesonide and formoterol had a $>20 \%$ deterioration in $\mathrm{SpO}_{2} /$ $\mathrm{FiO}_{2}$. The strongest signal was in the largest subgroup of patients who had pneumonia as a risk factor for ARDS. Currently, these results are being tested in a randomized, placebo-controlled phase 2 trial of 600 patients hospitalized for severe pneumonia with hypoxemia. The primary endpoint is acute respiratory failure defined as any combination of HFNO, non-invasive ventilation (NIV), or IMV for $>36 \mathrm{~h}$ (ARREST PNEUMONIA, NCT04193878). Together, these studies demonstrate the potential benefit of repurposing inexpensive, safe medications for early use to prevent respiratory failure from various etiologies of acute lung injury.

An investigational agent, AP301, increases AFC by activating epithelial sodium channels $(\mathrm{ENaC})$ in alveolar epithelial cells. In a phase 2 a trial of 40 mechanically ventilated patients with ARDS, Krenn et al. studied the effect of inhaled AP301 versus placebo (0.9\% saline) [58]. Changes in extravascular lung water measured by $\mathrm{PICCO}^{\circledR}$ thermodilution were not significantly different between groups overall, but extravascular lung water was significantly reduced in a post hoc subgroup of treated patients with greater baseline severity of illness (SOFA $>11$ ). Early treatment of acute lung injury with inhaled therapies offers a promising potential paradigm shift for the prevention of respiratory failure. However, further study in phase 2 and 3 trials to identify optimal selection of agents, timing of delivery, and sub-phenotypes of patients to target is needed.

\section{Novel therapies: mesenchymal stromal cells}

Personalization of novel therapies may rely on a detailed understanding of their biological mechanisms. There are considerable pre-clinical data that support the rationale for testing allogeneic mesenchymal stromal cells (MSCs) for the treatment of ARDS [59-61]. The potential mechanisms of benefit for reducing lung injury and enhancing lung repair are summarized in Fig. 3. MSCs can reduce lung vascular injury, perhaps in part by release of angiopoietin-1 that counteracts increased lung vascular protein permeability induced by angiopoietin- 2 in both infectious and non-infectious causes of lung injury [62, 63]. In addition, MSCs may reduce the severity of epithelial injury by several pathways $[64,65]$. MSCs also have anti-bacterial properties that have been demonstrated in both mice and the human lung, mediated by release of 
anti-microbial peptides such as LL-37 and an increase in macrophage phagocytosis [66].

Clinical trials have demonstrated no safety concerns and possible benefit in terms of improved oxygenation (by the oxygenation index) when analyzed by the viability of the MSCs $[67,68]$. A recent study of the mini-BAL collected $48 \mathrm{~h}$ after treatment in a subset of these patients (27/60) showed that treatment with MSCs reduced BAL concentrations of total protein and mediators of lung injury, including sTNFR1 and angiopoietin-2 [69]. These data are the first direct evidence that MSCs can have a favorable effect on reducing the biologic severity of ARDS. A multicenter phase $2 \mathrm{~b}$ trial of MSCs versus placebo for ARDS is underway (NCT03818854), and trials of MSCs for ARDS are in progress with considerable variation in the dose and source (bone marrow vs. umbilical cord for example) of the MSCs. Importantly, the biologic actions of MSCs in the airspaces likely depend upon the pulmonary microenvironment [70,71], suggesting that populations may respond differentially to treatment depending upon their primary ARDS risk factor (for example, infectious etiology). Thus, there are likely further opportunities to personalize MSC therapy even if no benefit is observed in unselected populations.

\section{Intelligent clinical trial design}

How should the heterogeneity of ARDS be incorporated in the approach to ARDS clinical trials? For some therapies, this heterogeneity may be irrelevant. The benefits of lung protective ventilation were demonstrated using a variation on the current clinical definition that captured patients with considerable variability in clinical severity, respiratory physiology, and biology [7, 72]. Supportive care trials might be relatively agnostic to underlying biologic pathways. The counter-argument to this more inclusive approach would be that heterogeneity of treatment effect has been identified even in trials of supportive care approaches $[1,5]$, including in the paradigmatic trial of low tidal volume ventilation [18], suggesting that clinical trials in ARDS should at least consider whether underlying heterogeneity is relevant. Table 3 provides an overview of incorporating heterogeneity into clinical trial design. The simplest approach is to pre-specify patient subgroups that will be analyzed for subgroup-specific benefits or harms. This approach has the advantage of not requiring a clear understanding of the optimal subgroup-therapy pairing/s and allowing for unexpected discoveries but is also inefficient and prone to type I error.

Two "enrichment" approaches to clinical trials may increase the chance of finding a therapeutic benefit: prognostic and predictive enrichment [73, 74]. Prognostic enrichment focuses on patients who are most likely to have poor disease-related outcomes. In ARDS, this approach typically means focusing on more severe disease. Predictive enrichment focuses on patients with a mechanistic phenotype most likely to be responsive to an intervention. During the COVID-19 pandemic, some trials of anti-inflammatory therapy have used this approach (e.g., RECOVERY's focus on IL-6 blockade in patients with CRP $>75 \mathrm{mg} / \mathrm{L}$ ) [45]. While both types of enrichment may increase the chance of identifying a signal, they also decrease generalizability and may risk missing effects in excluded patients. Predictive enrichment approaches informed by over-confidence in understanding of disease mechanisms could also potentially result in harm if the wrong patient subgroup is targeted [75]. Thus, predictive enrichment may be best reserved for situations in which a strong subgroup-specific treatment benefit has already been observed in more inclusive clinical trials [4].

One innovative approach to incorporating ARDS heterogeneity into clinical trials is to compare a personalized treatment strategy to a "one-size-fits-all" approach, as in the LIVE trial [23]. This study compared personalization of mechanical ventilation parameters to radiographic phenotype (diffuse vs. focal) to standard lung protective ventilation regardless of radiographic phenotype. This approach provides a measure of effectiveness in addition to efficacy, but the trial design is fairly complex and requires either an understanding of or assumptions about the best pairing between subgroup and treatment strategy.

A final innovative approach is the adaptive clinical trial. In its simplest form, this approach stratifies randomization by pre-specified subgroup and conducts interim analyses to identify subgroup-specific effects of treatment; one or more subgroups may then be dropped on the basis of these interim analyses. More complex iterations of this approach adjust randomization ratios to favor specific subgroups on the basis of interim results (so-called response-adaptive randomization), and/ or incorporate a platform trial design facilitating multiple pairings of subgroups with treatments [76]. This approach allows trialists to learn as they go regarding the optimal pairing of treatment and subgroup while avoiding the inefficiencies of the standard RCT design with subgroup analysis only at trial conclusion. However, it also requires a much more complex statistical analytic approach that may be met with some skepticism by readers used to more traditional designs.

\section{A global perspective on personalized medicine for ARDS}

Context, including regional and economic context, impacts the personalization of therapies for ARDS. Personalizing therapies to a specific clinical setting may be as necessary as individual patient personalization. While the overwhelming majority of critical 


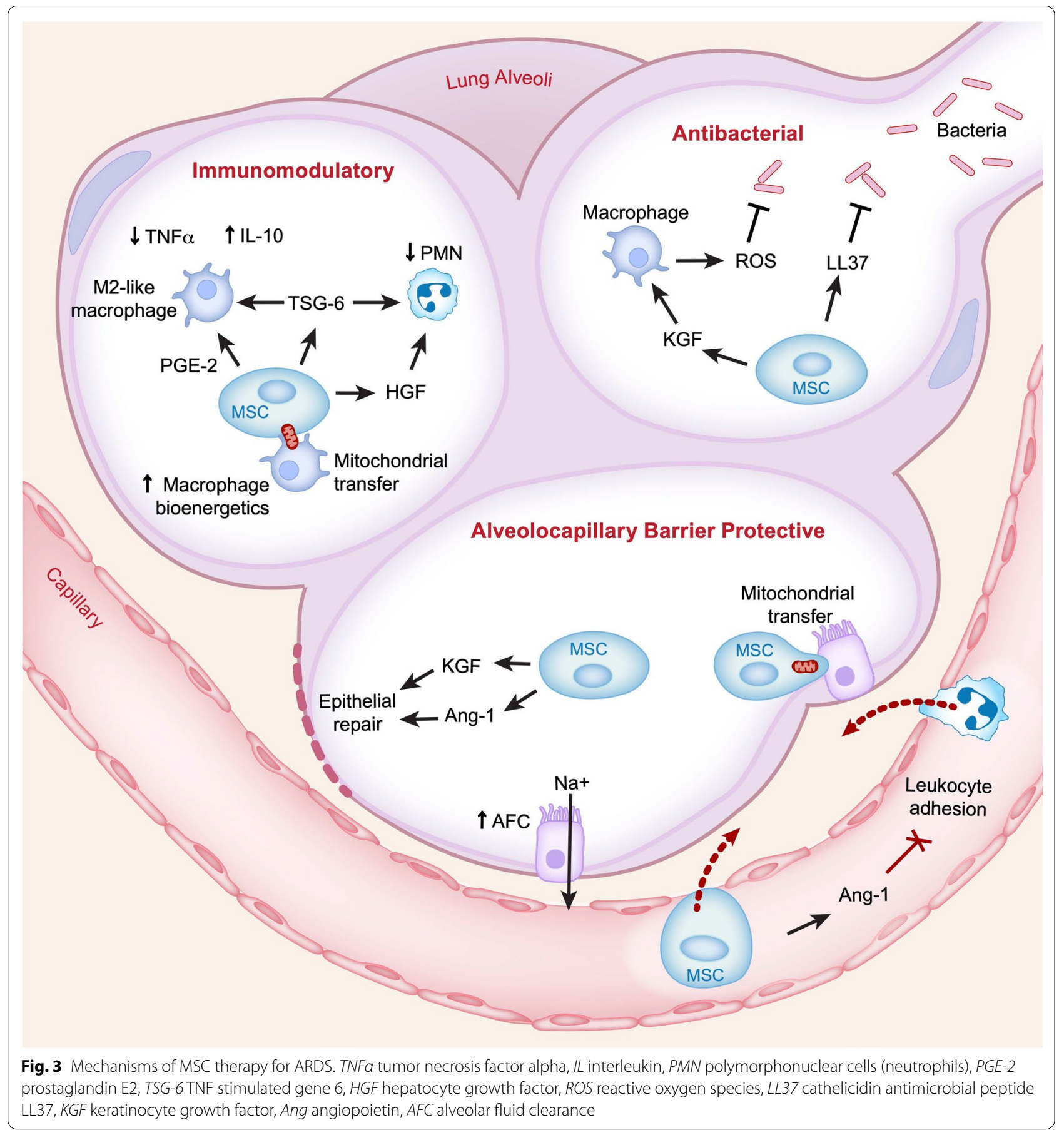

care research occurs in high-income countries (HICs), $87 \%$ of the world's population lives in low- or middleincome countries (LMICs) [77]. This economic context influences the predominant risk factors and biologic pathways leading to ARDS, the background physiologic environments of patients who develop ARDS, and the clinical resources available to diagnose and treat ARDS.
Different clinical insults predisposing to ARDS likely trigger different molecular pathways. While infection underlies ARDS in the majority of cases in HICs, trauma is a significant contributor in LMICs $[78,79]$. Within infectious causes, malaria, dengue fever, and leptospirosis need to be studied in LMICs $[80,81]$. One example of how this might be important, even for supportive therapies, is evident in sepsis care. While 


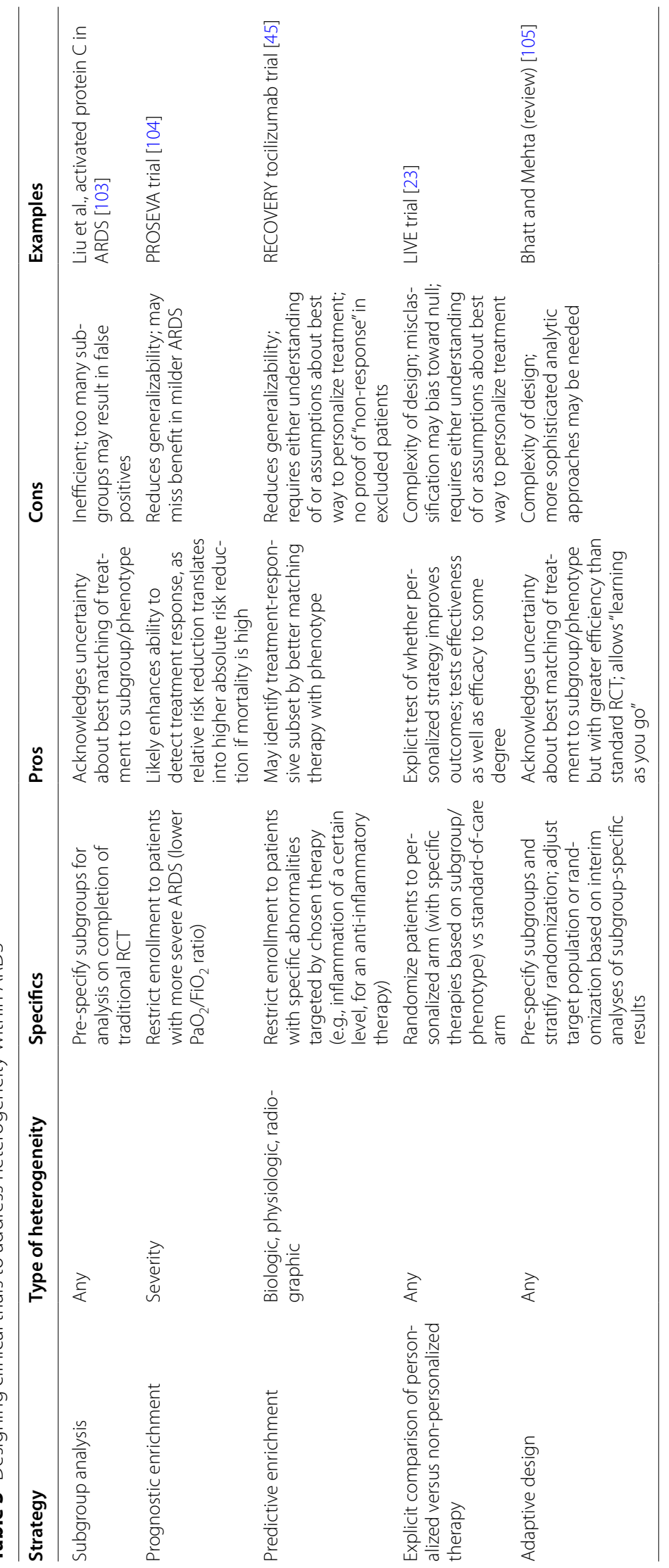


HIC studies have shown benefit from a clinical fluid resuscitation protocol for sepsis, a study of a comparable resuscitation protocol in Zambia demonstrated harm; one possible explanation for this finding was the high rate of subacute tuberculosis as the underlying cause of sepsis in the Zambian study [82]. Variability in patients' background pathophysiology prior to the onset of ARDS may also have an impact on targetable molecular pathways. Patients in LMICs versus HICs have very different characteristics by age, nutritional status, body mass index, infectious versus non-communicable comorbidities, and potentially population genetic trends. All of these may influence the targets for ARDS therapy in a given patient or population.

Resources may also impact which therapies provide benefit. For example, high flow nasal oxygen (HFNO) has been shown to decrease intubation rates but has not consistently reduced mortality in HICs [83]. In settings where intubation and mechanical ventilation are frequently unavailable, a decrease in need for intubation could conceivably translate to improvement in mortality. One study found that HFNC could decrease mortality in a model simulating scarce ventilators secondary to COVID-19 [84]; another study in children with hypoxemia in East Africa suggests that HFNC may confer a mortality benefit in that setting [85].

For personalized medicine in ARDS to be globally relevant, it needs to be developed in all regions of the world, including the resource-variable settings of LMICs [86]. This means that ARDS must be defined in such a way that it can be recognized and studied in a wide variety of resource contexts [79, 87]. This also requires a commitment to invest in the staff and infrastructure needed for diverse LMIC sites across the world to participate in ARDS trials [88]. The details of epidemiologic, resource, and practice characteristics must be documented, so that differences in study outcomes between sites can be understood and interpreted within the contexts in which they were produced [86]. Finally, studies in HIC sites should include both more and less complex diagnostics to allow correlations to be made and validated, thus facilitating the use of less complex diagnostics in LMICs. This includes imaging (chest radiograph vs. ultrasound), oxygenation (arterial blood gases vs. pulse oximetry), and biomarkers (plasma biomarkers vs. readily available clinical data) [89-91]. Personalizing ARDS treatments within discrete HIC populations and hoping that these therapies will translate to the majority of the world living in LMICs is not an adequate strategy. The development of targeted therapies for ARDS must include diverse peoples and populations from the outset.

\section{Conclusions}

The mainstay of ARDS treatment remains optimal supportive therapy with lung protective ventilation, proning, and a fluid conservative strategy, but the prospect of personalized therapies offers promise for further advances in treating ARDS. Although the heterogeneity of ARDS in some ways presents a challenge for personalization, it also provides a rich landscape with many opportunities for further investigation. By identifying clinical and biological characteristics that may differentially respond to existing and investigational treatments, clinical trials can be enriched in an adaptive manner. Pharmacologic and supportive interventions can be targeted by the stage of the syndrome of respiratory failure (such as early vs. late ARDS), ARDS risk factor, emerging biologic phenotypes, and individual pulmonary mechanics. These investigations must take into account variable resources as the study of ARDS and other critical illness syndromes expands globally to ensure that new discoveries carry maximal impact across diverse populations.

\section{Acknowledgements \\ The authors would like to acknowledge Diana Lim for her contributions to figure preparation.}

\section{Authors' contributions}

KDW and MAM conceived of the conceptual framework and structure of the article and collated individual author contributions. All authors contributed to the initial drafting of the manuscript. JRB, DA, and CSC created the tables. KDW and MAM contributed to figure design. All authors provided critical feedback for the final draft of the manuscript. All authors read and approved the final manuscript.

\section{Funding}

There was no specific funding support for this article.

\section{Availability of data and materials}

Data sharing not applicable to this article as no datasets were generated or analyzed during the current study.

\section{Declarations}

Ethics approval and consent to participate Not applicable.

\section{Consent for publication}

Not applicable.

\section{Competing interests}

KDW has received funding from NIH 5T32GM8440-24. DFM: Funding for PHIND trial from Innovate UK; grants/contracts from NIHR, Wellcome Trust, MRC, Northern Ireland HSC R\&D division, and Novavax as an investigator for ARDS and Covid-19 trials; patent from Queen's Belfast University for novel treatment for inflammatory disease (USB962032); consulting fees from Bayer, GlaxoSmithKline, Boehringer Ingelheim, Novartis, and Eli Lilly for the study of ARDS and Covid-19; Speaker fees from GlaxoSmithKline for educational seminars; DSMB member for Vir Biotechnology, Inc. and Faron Pharmaceuticals; Co-director of research for the Intensive Care Society; Director of EME program for MRC/NIHR. Spouse has received consultancy fees from Insmed and the California Institute for Regenerative medicine. JEL has received a grant from the NIH (UH3HL 141722) to study inhaled budesonide and formoterol for the treatment of hospitalized patients with pneumonia and hypoxemia for the prevention of acute respiratory failure. JRB: Grant funding from NIH grants 
K23-HL133489 and R21-HL145506. Consulting fees from Sedana Medical and Biomarck Pharmaceuticals for clinical trial design/planning, and Hamilton Medical for work as a medical monitor. DA has received a public grant through the national program "Programme d'Investissements d'avenir" under the reference ANR-18-RHUS-0004 for investigating corticosteroid therapy in COVID-19 and sepsis. This work is part of Federations Hospitalo-universitaires (FHU) Saclay and Paris Seine Nord Endeavour to PerSonalize Interventions for Sepsis (SEPSIS). EDR declares no competing interests. CSC: Grant funding from the NIH for the investigation of ARDS; grant support from Roche/Genentech, and Bayer for observational studies of ARDS; consultancy fees from Roche/ Genentech, Bayer, Gen1e Life Sciences, and Vasomune; fees for serving on the medical board of Prometric and Quark Pharmaceuticals; personal fees from Quantum Leap Healthcare Collaborative. MAM: Grant funding from the $\mathrm{NIH}$ for the investigation of ARDS; grant support from Roche/Genentech for observational studies of ARDS; consulting income from Citius Pharmaceuticals, Johnson and Johnson, and Novartis.

\section{Author details}

${ }^{1}$ Cardiovascular Research Institute, University of California San Francisco, 513 Parnassus Avenue, HSE 760, San Francisco, CA 94143, USA. ${ }^{2}$ Belfast Health and Social Care Trust, Royal Victoria Hospital and Wellcome-Wolfson Institute for Experimental Medicine, Queen's University Belfast, Belfast, UK. ${ }^{3}$ Division of Pulmonary, Allergy, and Critical Care Medicine, Stanford University, Stanford, CA, USA. ${ }^{4}$ Center for Acute Respiratory Failure and Division of Pulmonary, Allergy, and Critical Care Medicine, Columbia University, New York, NY, USA. ${ }^{5}$ Department of Intensive Care, FHU SEPSIS, and RHU RECORDS, Hôpital Raymond Poincaré (APHP), Garches, France. ${ }^{6}$ Laboratory of Infection \& Inflammation, School of Medicine Simone Veil, INSERM, University Versailles Saint Quentin, University Paris Saclay, Garches, France. ${ }^{7}$ Harvard Medical School and Division of Pulmonary, Critical Care, and Sleep Medicine, Beth Israel Deaconess Medical Center, Boston, MA, USA. ${ }^{8}$ Departments of Medicine and Anesthesia, University of California, San Francisco, San Francisco, CA, USA.

Received: 12 August 2021 Accepted: 9 November 2021

Published online: 23 November 2021

\section{References}

1. Calfee CS, Delucchi K, Parsons PE, Thompson BT, Ware LB, Matthay MA, Network NA. Subphenotypes in acute respiratory distress syndrome: latent class analysis of data from two randomised controlled trials. Lancet Respir Med. 2014;2(8):611-20.

2. Sinha P, Delucchi KL, Thompson BT, McAuley DF, Matthay MA, Calfee CS, Network NA. Latent class analysis of ARDS subphenotypes: a secondary analysis of the statins for acutely injured lungs from sepsis (SAILS) study. Intensive Care Med. 2018;44(11):1859-69.

3. Sinha P, Delucchi KL, Chen Y, Zhuo H, Abbott J, Wang C, Wickersham N, McNeil JB, Jauregui A, Ke S, Vessel K, Gomez A, Hendrickson CM, Kangelaris KN, Sarma A, Leligdowicz A, Liu KD, Matthay MA, Ware LB, Calfee CS. Latent class analysis-derived subphenotypes are generalisable to observational cohorts of acute respiratory distress syndrome: a prospective study. Thorax. 2021. https://doi.org/10.1136/thora xjnl-2021-217158.

4. Calfee CS, Delucchi KL, Sinha P, Matthay MA, Hackett J, Shankar-Hari M, McDowell C, Laffey JG, O'Kane CM, McAuley DF, et al. Acute respiratory distress syndrome subphenotypes and differential response to simvastatin: secondary analysis of a randomised controlled trial. Lancet Respir Med. 2018;6(9):691-8.

5. Famous KR, Delucchi K, Ware LB, Kangelaris KN, Liu KD, Thompson BT, Calfee CS, Network A. Acute respiratory distress syndrome subphenotypes respond differently to randomized fluid management strategy. Am J Respir Crit Care Med. 2017;195(3):331-8.

6. Matthay MA, Zemans RL, Zimmerman GA, Arabi YM, Beitler JR, Mercat A, Herridge M, Randolph AG, Calfee CS. Acute respiratory distress syndrome. Nat Rev Dis Primers. 2019;5(1):18.

7. Acute Respiratory Distress Syndrome Network, Brower RG, Matthay MA, Morris A, Schoenfeld D, Thompson BT, Wheeler A. Ventilation with lower tidal volumes as compared with traditional tidal volumes for acute lung injury and the acute respiratory distress syndrome. N Engl J Med. 2000;342(18):1301-8.
8. Chiumello D, Carlesso E, Cadringher P, Caironi P, Valenza F, Polli F, Tallarini F, Cozzi P, Cressoni M, Colombo A, et al. Lung stress and strain during mechanical ventilation for acute respiratory distress syndrome. Am J Respir Crit Care Med. 2008;178(4):346-55.

9. Cressoni M, Cadringher P, Chiurazzi C, Amini M, Gallazzi E, Marino A, Brioni M, Carlesso E, Chiumello D, Quintel M, et al. Lung inhomogeneity in patients with acute respiratory distress syndrome. Am J Respir Crit Care Med. 2014;189(2):149-58.

10. Kneyber MC, Zhang H, Slutsky AS. Ventilator-induced lung injury. Similarity and differences between children and adults. Am J Respir Crit Care Med. 2014;190(3):258-65.

11. Calfee CS, Ware LB, Eisner MD, Parsons PE, Thompson BT, Wickersham N, Matthay MA, Network NA. Plasma receptor for advanced glycation end products and clinical outcomes in acute lung injury. Thorax. 2008;63(12):1083-9.

12. McNamee JJ, Gillies MA, Barrett NA, Perkins GD, Tunnicliffe W, Young D, Bentley A, Harrison DA, Brodie D, Boyle AJ, et al. Effect of lower tidal volume ventilation facilitated by extracorporeal carbon dioxide removal versus standard care ventilation on 90-day mortality in patients with acute hypoxemic respiratory failure: the REST randomized clinical trial. JAMA. 2021;326:1013-23.

13. Amato MB, Meade MO, Slutsky AS, Brochard L, Costa EL, Schoenfeld DA, Stewart TE, Briel M, Talmor D, Mercat A, et al. Driving pressure and survival in the acute respiratory distress syndrome. N Engl J Med. 2015;372(8):747-55.

14. Beitler JR, Majumdar R, Hubmayr RD, Malhotra A, Thompson BT, Owens RL, Loring SH, Talmor D. Volume delivered during recruitment maneuver predicts lung stress in acute respiratory distress syndrome. Crit Care Med. 2016;44(1):91-9.

15. Terragni PP, Filippini C, Slutsky AS, Birocco A, Tenaglia T, Grasso S, Stripoli T, Pasero D, Urbino R, Fanelli V, et al. Accuracy of plateau pressure and stress index to identify injurious ventilation in patients with acute respiratory distress syndrome. Anesthesiology. 2013;119(4):880-9.

16. Becher T, Buchholz V, Hassel D, Meinel T, Schadler D, Frerichs I, Weiler N. Individualization of PEEP and tidal volume in ARDS patients with electrical impedance tomography: a pilot feasibility study. Ann Intensive Care. 2021;11(1):89.

17. Mattingley JS, Holets SR, Oeckler RA, Stroetz RW, Buck CF, Hubmayr $\mathrm{RD}$. Sizing the lung of mechanically ventilated patients. Crit Care. 2011;15(1):R60

18. Goligher EC, Costa ELV, Yarnell CJ, Brochard L, Stewart TE, Tomlinson G, Brower RG, Slutsky AS, Amato MPB. Effect of lowering Vt on mortality in acute respiratory distress syndrome varies with respiratory system elastance. Am J Respir Crit Care Med. 2021;203(11):1378-85.

19. Pereira Romano ML, Maia IS, Laranjeira LN, Damiani LP, Paisani DM, Borges MC, Dantas BG, Caser EB, Victorino JA, Filho WO, et al. Driving pressure-limited strategy for patients with acute respiratory distress syndrome. A pilot randomized clinical trial. Ann Am Thorac Soc. 2020;17(5):596-604.

20. Combes A, Hajage D, Capellier G, Demoule A, Lavoue S, Guervilly C, Da Silva D, Zafrani L, Tirot P, Veber B, et al. Extracorporeal membrane oxygenation for severe acute respiratory distress syndrome. N Engl J Med. 2018;378(21):1965-75.

21. Writing Group for the Alveolar Recruitment for Acute Respiratory Distress Syndrome Trial Investigators, Cavalcanti AB, Suzumura EA, Laranjeira LN, Paisani DM, Damiani LP, Guimaraes HP, Romano ER, Regenga MM, Taniguchi LNT, et al. Effect of lung recruitment and titrated positive end-expiratory pressure (PEEP) versus low peep on mortality in patients with acute respiratory distress syndrome: a randomized clinical trial. JAMA. 2017:318(14):1335-45.

22. Beitler JR, Sarge T, Banner-Goodspeed VM, Gong MN, Cook D, Novack V, Loring SH, Talmor D, Group EP-S. Effect of titrating positive end-expiratory pressure (PEEP) with an esophageal pressure-guided strategy versus an empirical high PEEP-Fio2 strategy on death and days free from mechanical ventilation among patients with acute respiratory distress syndrome: a randomized clinical trial. JAMA. 2019;321(9):846-57.

23. Constantin JM, Jabaudon M, Lefrant JY, Jaber S, Quenot JP, Langeron O, Ferrandiere M, Grelon F, Seguin P, Ichai C, et al. Personalised mechanical ventilation tailored to lung morphology versus low positive end-expiratory pressure for patients with acute respiratory distress syndrome 
in France (the LIVE study): a multicentre, single-blind, randomised controlled trial. Lancet Respir Med. 2019;7(10):870-80.

24. Costa EL, Borges JB, Melo A, Suarez-Sipmann F, Toufen C Jr, Bohm SH, Amato MB. Bedside estimation of recruitable alveolar collapse and hyperdistension by electrical impedance tomography. Intensive Care Med. 2009;35(6):1132-7.

25. Chen L, Del Sorbo L, Grieco DL, Junhasavasdikul D, Rittayamai N, Soliman I, Sklar MC, Rauseo M, Ferguson ND, Fan E, et al. Potential for lung recruitment estimated by the recruitment-to-inflation ratio in acute respiratory distress syndrome: a clinical trial. Am J Respir Crit Care Med. 2020;201(2):178-87.

26. Madahar P, Talmor D, Beitler JR. Transpulmonary pressure-guided ventilation to attenuate atelectrauma and hyperinflation in acute lung injury. Am J Respir Crit Care Med. 2021;203(8):934-7.

27. Gattinoni L, Tonetti T, Cressoni M, Cadringher P, Herrmann P, Moerer O, Protti A, Gotti M, Chiurazzi C, Carlesso E, et al. Ventilator-related causes of lung injury: the mechanical power. Intensive Care Med. 2016:42(10):1567-75.

28. Cressoni M, Gotti M, Chiurazzi C, Massari D, Algieri I, Amini M, Cammaroto A, Brioni M, Montaruli C, Nikolla K, et al. Mechanical power and development of ventilator-induced lung injury. Anesthesiology. 2016;124(5):1100-8.

29. Costa ELV, Slutsky A, Brochard LJ, Brower R, Serpa-Neto A, Cavalcanti AB, Mercat A, Meade M, Morais CCA, Goligher E, et al. Ventilatory variables and mechanical power in patients with acute respiratory distress syndrome. Am J Respir Crit Care Med. 2021;204:303-11.

30. Bos LDJ, Scicluna BP, Ong DSY, Cremer O, van der Poll T, Schultz MJ. Understanding heterogeneity in biologic phenotypes of acute respiratory distress syndrome by leukocyte expression profiles. Am J Respir Crit Care Med. 2019;200(1):42-50.

31. Sinha P, Calfee CS, Cherian S, Brealey D, Cutler S, King C, Killick C, Richards $\mathrm{O}$, Cheema Y, Bailey $\mathrm{C}$, et al. Prevalence of phenotypes of acute respiratory distress syndrome in critically ill patients with COVID-19: a prospective observational study. Lancet Respir Med. 2020;8(12):1209-18.

32. Heijnen NFL, Hagens LA, Smit MR, Cremer OL, Ong DSY, van der Poll T, van Vught LA, Scicluna BP, Schnabel RM, van der Horst ICC, et al. Biological subphenotypes of acute respiratory distress syndrome show prognostic enrichment in mechanically ventilated patients without acute respiratory distress syndrome. Am J Respir Crit Care Med. 2021;203(12):1503-11.

33. Whitney JE, Feng R, Koterba N, Chen F, Bush J, Graham K, Lacey SF, Melenhorst JJ, Parikh SM, Weiss SL, et al. Endothelial biomarkers are associated with indirect lung injury in sepsis-associated pediatric acute respiratory distress syndrome. Crit Care Explor. 2020;2(12):e0295.

34. Calfee CS, Janz DR, Bernard GR, May AK, Kangelaris KN, Matthay MA, Ware LB. Distinct molecular phenotypes of direct versus indirect ARDS in single-center and multicenter studies. Chest. 2015;147(6):1539-48.

35. Larsen R, Gozzelino R, Jeney V, Tokaji L, Bozza FA, Japiassu AM, Bonaparte D, Cavalcante MM, Chora A, Ferreira A, et al. A central role for free heme in the pathogenesis of severe sepsis. Sci Transl Med. 2010;2(51):51ra71.

36. Baek JH, D'Agnillo F, Vallelian F, Pereira CP, Williams MC, Jia Y, Schaer DJ, Buehler PW. Hemoglobin-driven pathophysiology is an in vivo consequence of the red blood cell storage lesion that can be attenuated in guinea pigs by haptoglobin therapy. J Clin Investig. 2012;122(4):1444-58.

37. Piagnerelli M, Boudjeltia KZ, Vanhaeverbeek M, Vincent JL. Red blood cell rheology in sepsis. Intensive Care Med. 2003;29(7):1052-61.

38. Fowler AA 3rd, Truwit JD, Hite RD, Morris PE, DeWilde C, Priday A, Fisher B, Thacker LR 2nd, Natarajan R, Brophy DF, et al. Effect of vitamin C infusion on organ failure and biomarkers of inflammation and vascular injury in patients with sepsis and severe acute respiratory failure: the CITRIS-ALI randomized clinical trial. JAMA. 2019;322(13):1261-70.

39. Janz DR, Bastarache JA, Peterson JF, Sills G, Wickersham N, May AK, Roberts $L J$ 2nd, Ware LB. Association between cell-free hemoglobin, acetaminophen, and mortality in patients with sepsis: an observational study. Crit Care Med. 2013;41 (3):784-90.

40. Janz DR, Bastarache JA, Rice TW, Bernard GR, Warren MA, Wickersham N, Sills G, Oates JA, Roberts $L$ 2nd, Ware LB, et al. Randomized, placebocontrolled trial of acetaminophen for the reduction of oxidative injury in severe sepsis: the acetaminophen for the reduction of oxidative injury in severe sepsis trial. Crit Care Med. 2015;43(3):534-41.

41. Rubenfeld GD, Caldwell E, Peabody E, Weaver J, Martin DP, Neff M, Stern EJ, Hudson LD. Incidence and outcomes of acute lung injury. N Engl J Med. 2005;353(16):1685-93.

42. W. H. O. Rapid Evidence Appraisal for COVID-19 Therapies Working Group, Shankar-Hari M, Vale CL, Godolphin PJ, Fisher D, Higgins JPT, Spiga F, Savovic J, Tierney J, Baron G, et al. Association between administration of IL-6 antagonists and mortality among patients hospitalized for COVID-19: a meta-analysis. JAMA. 2021;326:499-518.

43. W. H. O. Rapid Evidence Appraisal for COVID-19Therapies Working Group, Sterne JAC, Murthy S, Diaz JV, Slutsky AS, Villar J, Angus DC, Annane D, Azevedo LCP, Berwanger O, et al. Association between administration of systemic corticosteroids and mortality among critically ill patients with COVID-19: a meta-analysis. JAMA. 2020;324(13):1330-41.

44. Matthay MA, Luetkemeyer AF. IL-6 receptor antagonist therapy for patients hospitalized for COVID-19: who, when, and how? JAMA. 2021;326:483.

45. Recovery Collaborative Group. Tocilizumab in patients admitted to hospital with COVID-19 (RECOVERY): a randomised, controlled, open-label, platform trial. Lancet. 2021;397(10285):1637-45.

46. Remap-Cap Investigators, Gordon AC, Mouncey PR, Al-Beidh F, Rowan KM, Nichol AD, Arabi YM, Annane D, Beane A, van Bentum-Puijk W, et al. Interleukin-6 receptor antagonists in critically ill patients with Covid-19. N Engl J Med. 2021;384(16):1491-502.

47. Recovery Collaborative Group, Horby P, Lim WS, Emberson JR, Mafham M, Bell JL, Linsell L, Staplin N, Brightling C, Ustianowski A, et al. Dexamethasone in hospitalized patients with Covid-19. N Engl J Med. 2021;384(8):693-704.

48. Annane D, Sebille V, Bellissant E, Ger-Inf-05 Study G. Effect of low doses of corticosteroids in septic shock patients with or without early acute respiratory distress syndrome. Crit Care Med. 2006;34(1):22-30.

49. Mathew D, Giles JR, Baxter AE, Greenplate AR, Wu JE, Alanio C, Oldridge DA, Kuri-Cervantes L, Pampena MB, D'Andrea K, et al. Deep immune profiling of COVID-19 patients reveals patient heterogeneity and distinct immunotypes with implications for therapeutic interventions. bioRxiv. 2020;27:1451.

50. Annane D, Bellissant E, Bollaert PE, Briegel J, Keh D, Kupfer Y, Pirracchio $\mathrm{R}$, Rochwerg B. Corticosteroids for treating sepsis in children and adults. Cochrane Database Syst Rev. 2019;12:CD002243.

51. Pirracchio R, Hubbard A, Sprung CL, Chevret S, Annane D. Rapid recognition of corticosteroid resistant or sensitive sepsis C: assessment of machine learning to estimate the individual treatment effect of corticosteroids in septic shock. JAMA Netw Open. 2020;3(12):e2029050.

52. Atabai K, Ware LB, Snider ME, Koch P, Daniel B, Nuckton TJ, Matthay MA. Aerosolized beta(2)-adrenergic agonists achieve therapeutic levels in the pulmonary edema fluid of ventilated patients with acute respiratory failure. Intensive Care Med. 2002;28(6):705-11.

53. Sakuma T, Folkesson HG, Suzuki S, Okaniwa G, Fujimura S, Matthay MA. Beta-adrenergic agonist stimulated alveolar fluid clearance in ex vivo human and rat lungs. Am J Respir Crit Care Med. 1997;155(2):506-12.

54. Perkins GD, McAuley DF, Thickett DR, Gao F. The beta-agonist lung injury trial (BALTI): a randomized placebo-controlled clinical trial. Am J Respir Crit Care Med. 2006;173(3):281-7.

55. Gao Smith F, Perkins GD, Gates S, Young D, McAuley DF, Tunnicliffe W, Khan Z, Lamb SE, Investigators B-s. Effect of intravenous beta-2 agonist treatment on clinical outcomes in acute respiratory distress syndrome (BALTI-2): a multicentre, randomised controlled trial. Lancet. 2012;379(9812):229-35.

56. National Heart Lung Blood Institute Acute Respiratory Distress Syndrome Clinical Trials Network, Matthay MA, Brower RG, Carson S, Douglas IS, Eisner M, Hite D, Holets S, Kallet RH, Liu KD, et al. Randomized, placebo-controlled clinical trial of an aerosolized beta(2)agonist for treatment of acute lung injury. Am J Respir Crit Care Med. 2011;184(5):561-8.

57. Festic E, Carr GE, Cartin-Ceba R, Hinds RF, Banner-Goodspeed V, Bansal V, Asuni AT, Talmor D, Rajagopalan G, Frank RD, et al. Randomized clinical trial of a combination of an inhaled corticosteroid and beta agonist in patients at risk of developing the acute respiratory distress syndrome. Crit Care Med. 2017;45(5):798-805. 
58. Krenn K, Lucas R, Croize A, Boehme S, Klein KU, Hermann R, Markstaller K, Ullrich R. Inhaled AP301 for treatment of pulmonary edema in mechanically ventilated patients with acute respiratory distress syndrome: a phase lla randomized placebo-controlled trial. Crit Care. 2017;21(1):194.

59. Laffey JG, Matthay MA. Fifty years of research in ARDS. Cell-based therapy for acute respiratory distress syndrome. Biology and potential therapeutic value. Am J Respir Crit Care Med. 2017;196(3):266-73.

60. Matthay MA, Pati S, Lee JW. Concise review: mesenchymal stem (stromal) cells: biology and preclinical evidence for therapeutic potential for organ dysfunction following trauma or sepsis. Stem Cells. 2017;35(2):316-24.

61. Maishan M, Kuebler W, Lim D. Progress and potential of mesenchymal stromal cell therapy in acute respiratory distress syndrome. In: Nikolic MZ, Hogan BL, editors. Lung stem cells in development, health and disease. Sheffield: European Respiratory Society; 2021. p. 353-72.

62. Bhandari V, Choo-Wing R, Lee CG, Zhu Z, Nedrelow JH, Chupp GL, Zhang X, Matthay MA, Ware LB, Homer RJ, et al. Hyperoxia causes angiopoietin 2-mediated acute lung injury and necrotic cell death. Nat Med. 2006;12(11):1286-93.

63. Calfee CS, Gallagher D, Abbott J, Thompson BT, Matthay MA, Network NA. Plasma angiopoietin-2 in clinical acute lung injury: prognostic and pathogenetic significance. Crit Care Med. 2012;40(6):1731-7.

64. Fang X, Neyrinck AP, Matthay MA, Lee JW. Allogeneic human mesenchymal stem cells restore epithelial protein permeability in cultured human alveolar type II cells by secretion of angiopoietin-1. J Biol Chem. 2010;285(34):26211-22.

65. Fang X, Abbott J, Cheng L, Colby JK, Lee JW, Levy BD, Matthay MA. Human mesenchymal stem (stromal) cells promote the resolution of acute lung injury in part through lipoxin A4. J Immunol. 2015;195(3):875-81.

66. Krasnodembskaya A, Song Y, Fang X, Gupta N, Serikov V, Lee JW Matthay MA. Antibacterial effect of human mesenchymal stem cells is mediated in part from secretion of the antimicrobial peptide LL-37. Stem Cells. 2010;28(12):2229-38.

67. Matthay MA, Calfee CS, Zhuo H, Thompson BT, Wilson JG, Levitt JE, Rogers AJ, Gotts JE, Wiener-Kronish JP, Bajwa EK, et al. Treatment with allogeneic mesenchymal stromal cells for moderate to severe acute respiratory distress syndrome (START study): a randomised phase $2 a$ safety trial. Lancet Respir Med. 2019;7(2):154-62.

68. Wilson JG, Liu KD, Zhuo H, Caballero L, McMillan M, Fang X, Cosgrove K, Vojnik R, Calfee CS, Lee JW, et al. Mesenchymal stem (stromal) cells for treatment of ARDS: a phase 1 clinical trial. Lancet Respir Med. 2015;3(1):24-32.

69. Wick KD, Leligdowicz A, Zhuo H, Ware LB, Matthay MA. Mesenchymal stromal cells reduce evidence of lung injury in patients with ARDS. JCI Insight. 2021;6(12):e148983.

70. Abreu SC, Hampton TH, Hoffman E, Dearborn J, Ashare A, Singh Sidhu K, Matthews DE, McKenna DH, Amiel E, Barua J, et al. Differential effects of the cystic fibrosis lung inflammatory environment on mesenchymal stromal cells. Am J Physiol Lung Cell Mol Physiol. 2020;319(6):L908-25.

71. Abreu SC, Rolandsson Enes S, Dearborn J, Goodwin M, Coffey A, Borg ZD, Dos Santos CC, Wargo MJ, Cruz FF, Loi R, et al. Lung inflammatory environments differentially alter mesenchymal stromal cell behavior. Am J Physiol Lung Cell Mol Physiol. 2019;317(6):L823-31.

72. Parsons PE, Eisner MD, Thompson BT, Matthay MA, Ancukiewicz M, Bernard GR, Wheeler AP, Network NARDSCT. Lower tidal volume ventilation and plasma cytokine markers of inflammation in patients with acute lung injury. Crit Care Med. 2005;33(1):1-6 (discussion 230-232).

73. U.S. Food \& Drug Administration. Enrichment strategies for clinical trials to support determination of effectiveness of human drugs and biological products guidance for industry. In: Administration FD, editor. Silver Spring: Center for Drug Evaluation and Research; 2019. p. 1-41.

74. Ware LB, Matthay MA, Mebazaa A. Designing an ARDS trial for 2020 and beyond: focus on enrichment strategies. Intensive Care Med. 2020;46(12):2153-6.

75. Meyer NJ, Reilly JP, Anderson BJ, Palakshappa JA, Jones TK, Dunn TG, Shashaty MGS, Feng R, Christie JD, Opal SM. Mortality benefit of recombinant human interleukin-1 receptor antagonist for sepsis varies by initial interleukin-1 receptor antagonist plasma concentration. Crit Care Med. 2018;46(1):21-8.

76. Barker AD, Sigman CC, Kelloff GJ, Hylton NM, Berry DA, Esserman LJ. I-SPY 2: an adaptive breast cancer trial design in the setting of neoadjuvant chemotherapy. Clin Pharmacol Ther. 2009;86(1):97-100.

77. Fleischmann C, Scherag A, Adhikari NK, Hartog CS, Tsaganos T, Schlattmann P, Angus DC, Reinhart K, International Forum of Acute Care T. Assessment of global incidence and mortality of hospital-treated sepsis. Current estimates and limitations. Am J Respir Crit Care Med. 2016;193(3):259-72.

78. Bellani G, Laffey JG, Pham T, Fan E, Brochard L, Esteban A, Gattinoni L, van Haren F, Larsson A, McAuley DF, et al. Epidemiology, patterns of care, and mortality for patients with acute respiratory distress syndrome in intensive care units in 50 countries. JAMA. 2016;315(8):788-800.

79. Riviello ED, Kiviri W, Twagirumugabe T, Mueller A, Banner-Goodspeed VM, Officer L, Novack V, Mutumwinka M, Talmor DS, Fowler RA. Hospital incidence and outcomes of the acute respiratory distress syndrome using the Kigali modification of the Berlin definition. Am J Respir Crit Care Med. 2016;193(1):52-9.

80. Kumar SS, Selvarajan Chettiar KP, Nambiar R. Etiology and outcomes of ARDS in a resource limited urban tropical setting. J Natl Med Assoc. 2018;110(4):352-7.

81. Graca L, Abreu IG, Santos AS, Graca L, Dias PF, Santos ML. Descriptive acute respiratory distress syndrome (ARDS) in adults with imported severe Plasmodium falciparum malaria: a 10 year-study in a Portuguese tertiary care hospital. PLOS ONE. 2020;15(7):e0235437.

82. Andrews B, Semler MW, Muchemwa L, Kelly P, Lakhi S, Heimburger DC, Mabula C, Bwalya M, Bernard GR. Effect of an early resuscitation protocol on in-hospital mortality among adults with sepsis and hypotension: a randomized clinical trial. JAMA. 2017;318(13):1233-40.

83. Luo MS, Huang GJ, Wu L. High flow nasal cannula compared with conventional oxygen therapy for acute hypoxemic respiratory failure. Intensive Care Med. 2019;45(8):1167-8.

84. Gershengorn HB, Hu Y, Chen JT, Hsieh SJ, Dong J, Gong MN, Chan CW. The impact of high-flow nasal cannula use on patient mortality and the availability of mechanical ventilators in COVID-19. Ann Am Thorac Soc. 2021;18(4):623-31.

85. Maitland K, Kiguli S, Olupot-Olupot P, Hamaluba M, Thomas K, Alaroker F, Opoka RO, Tagoola A, Bandika V, Mpoya A, et al. Randomised controlled trial of oxygen therapy and high-flow nasal therapy in African children with pneumonia. Intensive Care Med. 2021;47(5):566-76.

86. Chowdhury S, Laux T, Morse M, Jenks A, Stonington S, Jain Y. Democratizing evidence production - a 51-year-old man with sudden onset of dense hemiparesis. N Engl J Med. 2019;381(16):1501-5.

87. Matthay MA, Thompson BT, Ware LB. The Berlin definition of acute respiratory distress syndrome: should patients receiving high-flow nasal oxygen be included? Lancet Respir Med. 2021;9:933-6.

88. Aryal D, Beane A, Dondorp AM, Green C, Haniffa R, Hashmi M, Jayakumar D, Marshall JC, McArthur CJ, Murthy S, et al. Operationalisation of the randomized embedded multifactorial adaptive platform for COVID19 trials in a low and lower-middle income critical care learning health system. Wellcome Open Res. 2021;6:14.

89. Vercesi V, Pisani L, van Tongeren PSI, Lagrand WK, Leopold SJ, Huson MMA, Henwood PC, Walden A, Smit M, Riviello ED, et al. External confirmation and exploration of the Kigali modification for diagnosing moderate or severe ARDS. Intensive Care Med. 2018;44(4):523-4.

90. Brown SM, Grissom CK, Moss M, Rice TW, Schoenfeld D, Hou PC, Thompson BT, Brower RG, Collaborators NNPN. Nonlinear imputation of $\mathrm{PaO}_{2} / \mathrm{FiO}_{2}$ from $\mathrm{SpO}_{2} / \mathrm{FiO}_{2}$ among patients with acute respiratory distress syndrome. Chest. 2016;150(2):307-13.

91. Sinha P, Churpek MM, Calfee CS. Machine learning classifier models can identify acute respiratory distress syndrome phenotypes using readily available clinical data. Am J Respir Crit Care Med. 2020;202(7):996-1004.

92. Hager DN, Krishnan JA, Hayden DL, Brower RG, Network ACT. Tidal volume reduction in patients with acute lung injury when plateau pressures are not high. Am J Respir Crit Care Med. 2005;172(10):1241-5.

93. Talmor D, Sarge T, Malhotra A, O'Donnell CR, Ritz R, Lisbon A, Novack $\mathrm{V}$, Loring SH. Mechanical ventilation guided by esophageal pressure in acute lung injury. N Engl J Med. 2008;359(20):2095-104.

94. Steinberg KP, Hudson LD, Goodman RB, Hough CL, Lanken PN, Hyzy R, Thompson BT, Ancukiewicz M, National Heart L, Blood Institute Acute 
Respiratory Distress Syndrome Clinical Trials N. Efficacy and safety of corticosteroids for persistent acute respiratory distress syndrome. N Engl J Med. 2006;354(16):1671-84.

95. Meduri GU, Golden E, Freire AX, Taylor E, Zaman M, Carson SJ, Gibson M, Umberger R. Methylprednisolone infusion in early severe ARDS: results of a randomized controlled trial. Chest. 2007;131(4):954-63.

96. Tongyoo S, Permpikul C, Mongkolpun W, Vattanavanit V, Udompanturak S, Kocak M, Meduri GU. Hydrocortisone treatment in early sepsisassociated acute respiratory distress syndrome: results of a randomized controlled trial. Crit Care. 2016;20(1):329.

97. Villar J, Ferrando C, Martinez D, Ambros A, Munoz T, Soler JA, Aguilar G, Alba F, Gonzalez-Higueras E, Conesa LA, et al. Dexamethasone treatment for the acute respiratory distress syndrome: a multicentre, randomised controlled trial. Lancet Respir Med. 2020;8(3):267-76.

98. Tomazini BM, Maia IS, Cavalcanti AB, Berwanger O, Rosa RG, Veiga VC, Avezum A, Lopes RD, Bueno FR, Silva M, et al. Effect of dexamethasone on days alive and ventilator-free in patients with moderate or severe acute respiratory distress syndrome and COVID-19: the CoDEX randomized clinical trial. JAMA. 2020;324(13):1307-16.

99. Dequin PF, Heming N, Meziani F, Plantefeve G, Voiriot G, Badie J, Francois B, Aubron C, Ricard JD, Ehrmann S, et al. Effect of hydrocortisone on 21-day mortality or respiratory support among critically ill patients with COVID-19: a randomized clinical trial. JAMA. 2020;324(13):1298-306.

100. Angus DC, Derde L, Al-Beidh F, Annane D, Arabi Y, Beane A, van Bentum-Puijk W, Berry L, Bhimani Z, Bonten M, et al. Effect of hydrocortisone on mortality and organ support in patients with severe COVID-19: the REMAP-CAP COVID-19 corticosteroid domain randomized clinical trial. JAMA. 2020;324(13):1317-29.

101. Jeronimo CMP, Farias MEL, Val FFA, Sampaio VS, Alexandre MAA, Melo GC, Safe IP, Borba MGS, Netto RLA, Maciel ABS, et al. Methylprednisolone as adjunctive therapy for patients hospitalized with coronavirus disease 2019 (COVID-19; Metcovid): a randomized, double-blind, phase IIb, placebo-controlled trial. Clin Infect Dis. 2021:72(9):e373-81.

102. Corral-Gudino L, Bahamonde A, Arnaiz-Revillas F, Gomez-Barquero J, Abadia-Otero J, Garcia-lbarbia C, Mora V, Cerezo-Hernandez A, Hernandez JL, Lopez-Muniz G, et al. Methylprednisolone in adults hospitalized with COVID-19 pneumonia: an open-label randomized trial (GLUCOCOVID). Wien Klin Wochenschr. 2021;133(7-8):303-11.

103. Liu KD, Levitt J, Zhuo H, Kallet RH, Brady S, Steingrub J, Tidswell M, Siegel MD, Soto G, Peterson MW, et al. Randomized clinical trial of activated protein $\mathrm{C}$ for the treatment of acute lung injury. Am J Respir Crit Care Med. 2008:178(6):618-23.

104. Guerin C, Reignier J, Richard JC, Beuret P, Gacouin A, Boulain T, Mercier E, Badet M, Mercat A, Baudin O, et al. Prone positioning in severe acute respiratory distress syndrome. N Engl J Med. 2013;368(23):2159-68.

105. Bhatt DL, Mehta C. Adaptive designs for clinical trials. N Engl J Med. 2016;375(1):65-74.

\section{Publisher's Note}

Springer Nature remains neutral with regard to jurisdictional claims in published maps and institutional affiliations.
Ready to submit your research? Choose BMC and benefit from:

- fast, convenient online submission

- thorough peer review by experienced researchers in your field

- rapid publication on acceptance

- support for research data, including large and complex data types

- gold Open Access which fosters wider collaboration and increased citations

- maximum visibility for your research: over $100 \mathrm{M}$ website views per year

At BMC, research is always in progress.

Learn more biomedcentral.com/submissions 